Article

\title{
Resilience of Traditional Livelihood Approaches Despite Forest Grabbing: Ogiek to the West of Mau Forest, Uasin Gishu County
}

\author{
Jemaiyo Chabeda-Barthe * and Tobias Haller \\ Institute of Social Anthropology, University of Bern, Lerchenweg 36, 3000 Bern 9, Switzerland; \\ tobias.haller@anthro.unibe.ch \\ * Correspondence: cjemaiyo@yahoo.com
}

Received: 15 October 2018; Accepted: 13 November 2018; Published: 16 November 2018

check for updates

\begin{abstract}
This paper is a summary of the findings of research work conducted in two case studies in the Rift Valley, Kenya. This study used the Neo-Institutional theory to interrogate how the rules and regulations (institutions involved) of the agrarian reform process in Kenya are constantly changing and helping to shape the livelihoods of social actors around Mau Forest. The first case study-Ndungulu, is a settlement scheme where the Ogiek ethnic community were resettled between 1995 and 1997 after the land clashes of 1992. The second case study is the Kamuyu cooperative farm, a post-colonial settlement scheme owned by a cooperative society that was founded in 1965 by members from the Kikuyu ethnic group. This study employed qualitative data collection methods intermittently between 2012 and 2017 for a total of two years. A total of 60 interviews were conducted for this research. Thirteen (13) of these were key informant interviews with experts on land. The qualitative interviews were complemented by participant observations and nine focus group discussions. The qualitative data from the interviews and focus group discussions were transcribed, coded and analyzed thematically. Observations documented as field notes were also analyzed to complement the study findings. In this paper, the challenges, bargaining position and power play between social actors and government institutions implicated in the agrarian reform process in Kenya has been brought to the forefront. For instance, due to the structural issues that date back to the colonial period, the Ogiek have found innovative ways to maintain their daily existence (e.g., maintaining traditional methods of apiculture in Mau Forest). However, constraints in accessing forest land has resulted in them taking desperate measures, namely; selling off land to the Kalenjin in what is called "distress land sales". On the contrary, the neighboring Kikuyu have maintained their land ownership status despite recurrent ethnic clashes that have occurred during general election years.
\end{abstract}

Keywords: forest land governance; Mau Forest; Ogiek; institutions; land grabbing; Community Land Act and customary law

\section{Background}

Ethnic conflict over land in the Rift Valley, Kenya is largely brought about by the land reform resettlement policies starting from the colonial era [1]. The British colonial government was responsible for reinforcing the adoption of land as private property as opposed to communal land ownership practised by native Africans. Land was cleared to pave way for developments such as the construction of the railway [2], ([3] p. 271). This led to the acquisition of African lands through the Crown Land Ordinance of 1915, the imposition of English tenure through individualisation and the transformation of customary land tenure systems [4-6]. This was notably in the Rift Valley, as well as central province also known as the 
"white highlands"; areas that were climatically suited for the British settlement and large-scale plantation (coffee, tea and pyrethrum) farming [5-9]. At the dawn of independence in 1963, ex-settler farms were available on the land market through a "willing buyer", "willing seller" arrangement [10].

This paper presents the changing institutional arrangements of land in pre and post-colonial regimes in Kenya and how this has challenged the resilience of Ogiek as actors within the Ndungulu settlement scheme. The study compares the Ogiek, to other dominant actors such as Kalenjin and neighboring community of the Kikuyu. The latter have been resilient despite ethnic clashes, due to an enabling political environment. Furthermore, according to [11], Kikuyu, men "muthuri" were always working towards wealth accumulation, gentrification and respectability. These Kikuyu cultural beliefs may have contributed to the thriving Kamuyu cooperative farm discussed later. Other actors include a community forest association called 'Leinguse peace and conflict management association', a local peace committee, a non-state actor; Mercy Corps non-governmental organization (NGO), the Assistant Chief's office (state actor who oversees informal land sales), and the African Court for Human and Peoples' Rights (ACHPR), an international court. The interactions between formal and informal actors is against the backdrop of a seemingly enabling domestic legal ${ }^{1}$ environment (enactment of 2016 Forest Conservation and Management Act and 2016 Community Land Act, discussed later in this article).

The land claims of Ogiek have been politicized from the colonial era onwards [12]. The institutional change from common property ownership of land and related resources to private and or state ownership is at the core of agrarian reform in Kenya. According to [13], p. 7, "Institutions are seen here as formal and informal 'rules of the game'. Constrains, norms, values and rules in the community, govern the said 'rules of the game'. These motivate the intra community dynamic (notably each of the three communities in this study has its own set of rules and norms) with regard to structure. Interactions within the community are related to the following factors; generation of wealth (economic) and maintaining social harmony (collective action)". Amongst the Ogiek, these interactions are extended to protecting and conserving the Mau Forest (sustainable resource use).

The skewed redistribution of land in the Rift Valley, has consequently created tension between three major categories of social actors; the 'so-called pastoralists ${ }^{2}$, see [14], such as Kalenjin sub groups [15], "forest dwellers" such as the Ogiek of Mau forest [16], and so-called "immigrant guests" [17], such as the Kikuyu ethnic group who traditionally are agriculturalists [18]. The eviction of the Ogiek is documented since colonial time. Firstly, the Carter Commission in 1932 failed to acknowledge minority communities like the Elgon Ogiek, Mau Ogiek and Sengwer [19], thus requiring them to integrate into acknowledged ethnic communal land areas. Secondly, the post-colonial government gazetted the forests and forcefully evicted Ogiek from the forest land [20].

Furthermore, the Constitution and the 2016 Forest Conservation and Management Act ${ }^{4}$ vests tenure in the Kenya Forest Service (KFS) ${ }^{5}$, albeit in trust for the nation. A combination of factors

1 For example, in Kenya there has been reform in land laws rather than policies to encourage social transformation ideologies on equality and equity. Taking land ownership for example, the Constitution of 2010, National Land Policy of 2009 and Land Act 2012, Land Registration Act of 2012 all promote land ownership anchored on formal title as the defining feature of property relations. However, this co-exists with and is constantly in tension with broader and dynamic social processes and institutions that shape property relations by constantly balancing between various competing claims and values, rights and obligations. The Community Land Act 2016 takes these factors into account.

2 In this study, I categorize Kalenjin as 'pastoralists' because pre-historically, they were pastoralists [14]. In addition, prominent Kalenjin leaders such as Deputy President William Ruto, addresses his Kalenjin community as "pastoralists" in public functions, to show the importance that the community places on livestock keeping. Notably, over the years, the Kalenjin have gradually interacted with Bantu speaking communities and have adapted arable farming and livestock keeping [15].

3 I also use the term "immigrant guests" because during the 2007 post-election violence, it was used to refer to Kikuyu who have migrated into the Rift Valley, see Jenkins, 2012 [17].

4 In Part IV (No.31), the new Forest Conservation and Management Act simply states that "all public forests in Kenya are vested in the service.". This leaves a loophole in the rights of those communities that consider forestland as ancestral land. Alden Wily (2018, p. 667) [21] argues that "complainant communities understandably consider the privatization of forest reserves as removing their forested community lands yet further from their grasp".

5 The Kenya Forest Service is a semi-autonomous agency set up in 2007 to conserve, develop and sustainably manage forest resources for the country's socio-economic development. It is managed by a board of directors drawn from both the private 
including but not limited to; the Ogiek's misunderstanding of the role of KFS, scarcity of land in Rift Valley and land grabbing have led to tensions near Mau Forest. All of these factors have contributed to recurring ethnic conflicts, especially among the aforementioned categories of communities and have resulted in thousands of displaced families. Furthermore, given the progressive legal environment in Kenya with regards to enactment of the Community Land Act 2016 and Forest Conservation and Management Act 2016, it still remains only to a certain extent that the Community Land Act can secure community forest land rights. Alden Wily (2018) provides an excellent analysis on how in some instances, the Forest Conservation and Management Act 2016 makes it difficult for communities to retain traditional forests as their land [21].

\section{Pre-Colonial Land Arrangement between Ogiek (Ndorobos) and other Communities}

The abundance of land was a main feature of pre-colonial land tenure systems in Kenya. The autochthones, otherwise known as indigenous communities, such as Maasai [22], and Ogiek [23]. (Ndorobo) were the original land owners in Rift Valley and central province respectively The 'Ndorobo' had what, Kitching (1980) [24] terms as the "honey barrel" rule. He states that "Ndorobos" regarded all forest areas in which they hung their honey barrels as "theirs" and therefore foreigners in an area inhabited by the "Ndorobo" would be subject to the hunter-gatherer rules of the 'Ndorobo' [24], pp. 282-283. The Ndorobo thought of themselves, and were regarded as Ndorobo, as long as they hunted and gathered. People classified themselves and others in terms of subsistence patterns and allegiance [25], p. $112^{6}$.

This transfer of land rights between natives and outsiders within the framework of customary law has been documented by Chauveau, et al. [26] p.14 as a widespread practice in West African societies. Chauveau, et al. terms this as 'tutorat" ${ }^{7}$ and states that it existed within the context of abundance of land and low population densities. The bilateral relationship between the tuteur and stranger is mediated by society. It is socially sanctioned and put into effect by the village authorities. The institution of tutorat is found in most non-market transfers such as 'inadequate loans and gifts' to individuals or groups of outsiders received into local communities [26].

In the context of pre-colonial tenure systems in Central and Rift Valley provinces of Kenya one could say that the Ndorobo (Ogiek) were the tuteurs of the Kikuyu. In the early 1900s records show that Kikuyu were entering into land transactions with neighboring communities in an amicable ${ }^{8}$ way unlike the Nandi who raided their neighbors to conquer land. Similarly, in South Rift Valley, the Maasai [28] ethnic group were the tuteurs of the Kalenjin.

In the case of 'Ndorobo' and Kikuyu, women played an important role in the pre-colonial land arrangements. Chauveau et al. (2006, p. 16) [26], illustrates how the tuteur $^{9}$ (an official representative of a lineage group) could not challenge the bundle of rights granted to his tenant, neither could he impose new obligations without the agreement of village authorities. The only expectation was

and public sectors that has the mandate to oversee the development of the entire forest sector. The Kenya Forest Service also regulates the harvesting of firewood by issuing licenses to any persons interested in the wood fuel from the forest.

6 Haugerud [25] has argued that in Central province of Kenya in the nineteenth century was made up of people with a long history of relations through trade, migration, marriage, clientage and adoption. Neither commercialization nor wealth was unknown in Central Kenya during the nineteenth century.

7 Chauveau, et al. [26] p. 14 defines the term tutorat as "the reciprocal social relations that develop when a stranger (or group of strangers) and his family are received into a local community for an indeterminate period, which may span generations. Transfers are effected through the transfer of land rights between a customary land owner 'tuteur' who is either a native or autochthone. The institution of Tutorat was embedded in client patron-relationships and socio-political relationships".

8 See Leakey (1952, p. 4) [27].

9 A type of collective tutorat at the village level (i) where the bilateral relations between tuteurs and strangers are entirely mediated by the social and political organization of the local society. A type of collective inter-village tutorat (ii) where the customary rules that determine relations with communities settled on the lands of an older village are same as those that define the relationships between a newcomer and his tuteur at village level. A type of individualized tutorat (iii) where the bilateral relationship between tuteur and stranger is very strong and seems relatively autonomous of the social and political organization of the local society. (Chauveau et al., 2006, p. 16) [26]. 
that the beneficiary, in the case of Kenya (the Kikuyu who had been tuteured by Ndorobo) had to respect the host's taboos, live in the village and adopt social and economically acceptable attitude. Kershaw (1997, p.19) [18] illustrates that these reciprocal social relations were realized between the Kikuyu and Ogiek (also referred to as Ndorobo), through mixed marriages. These pre-colonial land agreements and arrangements are important for this study because they show how customary law is malleable and dynamic. This echoes the work by Joireman, 2011 [29] and Chanock, 1985 [30].

\section{Debates on Ogiek's Right to Ancestral Land}

\subsection{Why Examine Conflict in Relation to Settlement Schemes and Landownership in Rift Valley?}

The root cause of conflict in the Rift Valley is attributed to the occurrence of high in-migration under a land tenure regime whose sole adjudicator, allocator and arbitrator of rights is the government of Kenya [9], p. 73. This is what Boone (2014) [9] terms as a 'statist' land regime. Ethnicity forms an interesting theme for discussing insecurity of land tenure in Kenya which has 42 ethnic communities. However, what seems to be ethnic-led conflict may actually be constructed through what Brubaker (2004) [31] has termed as ethnic groupings. Theories on constructivism and ethnicity debates form the bulk of literature about the land question in Rift Valley, Kenya. Many scholars [32-35] have argued that what exists is politically driven ethnic conflict whose negative impact may be greater than that of moral ethnicity.

The most recent statistics made by the then Office of the Prime Minister ${ }^{10}$ in 2009 show that through a series of forest excisions and encroachment, some 107,707 hectares representing approximately 25 per cent of the Mau Complex area, has been converted to settlement and farmlands over the last 15 years. Through the excisions of 2001 alone, $61,586.5$ hectares of forest in the Mau Forests Complex was to be converted to settlements. This research study aimed at ensuring that the arguments were not lost in the "Kalenjin" versus Kikuyu ethnic-conflict rhetoric. The study sought to interrogate and situate the precarious land tenure arrangements negotiated by different ethnic groups existing in the same geographical space. The study illuminates the underlying intra and inter community land rights dynamic experienced by Ogiek, Kalenjin and Kikuyu. This is because the sub groups of Kalenjin are from areas that are in close proximity to the Ogiek who have settled in Ndungulu.

\subsection{Salient Debates}

To date, scholarly explanations for agrarian processes have dealt with social categories based on economic classes; namely "peasant", "farmer", and "worker". These have left out the Ogiek who are hunter-gatherers, from the agrarian reform process because they do not fit in the aforementioned mode of classification. This has invigorated the debates on indigenous people's rights; thus, advancing the argument that indigenous communities are best placed to care for the natural resources, notably the forests. The competing sides, one strongly rooted in the belief of tragedy of the commons versus the customary practices of forest husbandry (indigenous knowledge systems, (IKSs) that is advocated by conservationists is what has led to renewal of interest in indigenous groups as conservationists. Theories on political ecology have also helped to reinforce these arguments. In addition, indigenous way of life is associated with communal subsistence.

Much of the debates on land rights for indigenous groups such as Ogiek have been reinvigorated and driven by international NGOs such as Survival International and a local NGO; Ogiek Peoples Development Programme, while others through international organizations such as Minority Rights Group in Europe and International Union for the Conservation of Nature (IUCN) Whakatane

10 Report of the Prime Minister's Taskforce on the Conservation of the Mau Forest complex. http://www.kws.go.ke/content/ mau-forest-restoration-publications. 
mechanism, see [36]. Regardless of the geographical location, the salient features within these debates revolve around two concepts; indigenous knowledge and natural resource management.

The reason why the belief in mutual benefit between indigenous communities and forests has gained ground is because; first, various theorists of political ecology echo the principals behind this belief. By marrying two disciplines namely; Political economy and cultural ecology, renowned anthropologists [37-39] were able to lay the foundation for the theory of political ecology. This theory illuminates the importance of local, minority and indigenous knowledge. Further, it underscores the importance of environmental impact on cultural processes within the political and economic contexts.

In other debates, that link indigenous people with conservation efforts, the tone has been nostalgic. For example, authors like Davis and Wali (1994) argue that the indigenous knowledge systems (IKS) that indigenous people in Latin America have maintained over the years are the link to sustaining "mother earth" in a time when tropical forests are facing destruction [40], as well as climate change $[41]^{11}$. In addition, anthropologists are also advancing theories on why communities are better placed to conserve the so-called protected areas such as forests [42].

The second reason why the Ogiek have gained popularity within these debates can be attributed to the fact that the indigenous way of life is associated with communal subsistence. This is seen as the antithesis of land-grabbing ${ }^{12}$ schemes whose foundation lies in individualized land tenure approach. However, not everyone agrees with these reason that advance the restitution of ancestral land and 'commons' to indigenous groups. More so, their ownership claims on fertile and productive areas such as Rift Valley and the forests. Using the example of the Maasai in Tanzania, Hodgson (2011, pp. 8-9) illustrates how external factors such as international NGOs and advocacy networks that have a transnational mandate compete against nation state to push ethnic groups to positioning themselves as 'indigenous' [22]. The reasons for this may vary.

Authors such as Médard (2008) $)^{13}$ and Branch et al. (2010) argue that there is an economic incentive behind the interest in being identified as a minority group [23,43]. According to Branch et al. (2010, p. 187), the first incentive is the financial returns in selling off the land acquired through these indigenous court claims [43]. The second incentive is to get access to resources from international ${ }^{14}$ Institutions that provide funds as well as create awareness about the authenticity ${ }^{15}$ of their "indigenousness". A counterargument has against these sort of generalizations. Wachira (2008, pp. 85-87) argues that looking at the situation of indigenous communities from a capitalist standpoint fails to take account of the fact that, while a community may have adopted a modern way of life, that in itself does not make that community unable to maintain its cultural and traditional practices [44].

\section{Materials and Methods}

\subsection{Theoretical Framework}

This study is anchored on the neo institutional theoretical framework. According to Ensminger (1998, pp. 1-2), Neo-Institutionalism is the study of how institutions affect the behavior of individuals and how individual behavior affects the evolution of institutions: pivotal to these relations is the role of incentives [45]. The approach enabled the study to focus on the role of the state and external economic, political, demographic and technical changes and how these influence prices for goods and

11 Speranza et al. (2009) correlates the usefulness of African indigenous knowledge systems and modern science for enhancing food security and climate change adaptation in Kenya [41].

12 Land grabbing is seen as part of the wider, large-scale land acquisition schemes to be embraced by African governments.

13 Médard (2008, pp.81-98) argues that the Ogiek of Mount Elgon or from Mau forest areas claim to be the autochthons of Rift Valley and are reclaiming forest land because of the potential benefits of owning highly fertile land in Rift Valley and not necessarily to revert back to their hunter-gatherer customary land administration system [23].

14 http://www.survivalinternational.org/news/10119.

15 The detailed information on the "indigenousness" of the Ogiek can be found on various websites such as the http://www. ogiekpeoples.org/. 
the terms of trade (changes in relative prices) in relation to the land related institutions in the study area. The relative prices then have an influence on the local level and lead to changes in informal, local institutions, organization, ideology and bargaining power of the different actors [46].

\subsection{Local and Topographic Characteristics of Uasin Gishu}

The area being researched is located in Kesses constituency, Uasin Gishu County in the Rift Valley province of Kenya as highlighted in Figure 1 below. Kesses is one of the six constituencies ${ }^{16}$ in Uasin Gishu County and has a population of 135,979 (Census 2009) and covers an area of approximately 299 square kilometers. The entire $3784 \mathrm{sq}$. $\mathrm{km}$. of Uasin Gishu is arable land. It is estimated that about $2354 \mathrm{sq}$. $\mathrm{km}$. of the land area is considered to be high potential whereas about $1430 \mathrm{sq} . \mathrm{km}$. is medium potential. There is neither marginal nor irrigated land in the district. Forest reserves occupy around 6100 hectares. The forests are Timboroa, Cengalo, Nabkoi, Lorenge, Kipkurere and Kapsaret (NEMA, 2013, p. 14) [47] ${ }^{17}$.

The two farming communities of Ndungulu (Ogiek and Kalenjin ethnic groups) and Kamuyu (Kikuyu ethnic group) are the case studies, see Yin, 2003 [48], for this research and are located in Lainguse sub-location of $\mathrm{Ol}^{\prime}$ Leinguse ${ }^{18}$ [49] location, Kesses constituency. Kesses is bordered to the north by Soy and Moiben whose residents are mainly from the Kalenjin sub ethnic groups of Keiyo and Nandi. In the south it is bordered by Tinderet, where the dominant ethnic group is the Kipsigis, while to the west, it is bordered by Nandi in which the dominant ethnic group is the Nandi. To the East it is bordered by Ainabkoi where there is a mix of Kalenjin subethnic groups and some Kikuyu settlement schemes.

16 There are other constituencies namely Ainabkoi, Kapseret, Moiben, Turbo and Soy. There are three local authorities namely Wareng County Council, covering the widest area with 21 wards, Eldoret Municipal council with 15 wards and Burnt Forest Town Council with 6 wards.

17 Statistics from the NEMA report were published before the establishment of county system of local governance. Uasin Gishu district is now called Uasin Gishu County.

18 According to the Kenya National Population Censu, 2009 [49], p. 145, the area of Ol'leinguse is 132 square kilometers, with a population density of 122. A total of 7983 are male, while 8122 are female. There are 3177 households in the Ol'leinguse location. 




Figure 1. Study area is specifically Burnt Forest, situated in Uasin Gishu County.

Figure 2 below shows Burnt forest commercial center situated along the Eldoret-Nairobi highway. The settlements schemes are situated near the forest areas in the center of the map. They were excised off the Tinderet and Ainabkoi forests (all part of the larger Mau Forest ecosystem). Forest cover has marginally reduced because of land fragmentation as is depicted in the image. The remaining forest areas, especially Kapilat, is used for ceremonial purposes such as male and female circumcision (done less and less over the years) among Ogiek and Kalenjin. In addition, traditional harvesting of honey as well as indigenous medicine is carried out by the Ogiek community. 




Figure 2. Map of the Burnt Forest Area showing Kamuyu farm and Ndungulu settlement.

\subsection{Description of Study Area: Ndungulu}

Since 1992, Kenya government began resettling Ogiek in Rift Valley, however there exists tensions between Ogiek and so called "cousins" (Kalenjin sub ethnic groups) who are settled in these areas. As highlighted in Figure 2, Ndungulu settlement scheme is officially registered in government records as Cheboror Farm Number 24,644 [47], p. 35"19. The word "Ndungulu" stands for 'salty water springs' in Maasai language. According to field interviews in 2017, Ogiek elders aged between 70 and 85 years of age, stated that the area was a watering point for Maasai cattle. Notably, both case studies of Ndungulu and Kamuyu are in $\mathrm{Ol}^{\prime}$ leinguse ${ }^{20}$ location, the smallest government-controlled administrative unit of Uasin Gishu ${ }^{21}$ County. The "Ndorobo" or Ogiek were resettled on these 740 hectares $^{22}$ farm as compensation for being evicted from the neighboring forests. These include; Bureti (Nabkoi Forest) Cheboror (Cenghalo Forest), Kipsangany, Sereng'onik Forest, Kipkurerek, and Ngatipkong ${ }^{23}$ (Kosabei forest). There are five villages on Ndungulu namely; Tachasis, Koibeiyo, Lengut, Tulwet and Kaptaragon. Asis means God in Ogiek language. The village that is named Tachasis is situated on the highest altitude point on the settlement farm and receives the first ray of sunlight in the morning. For the Ogiek, God is associated with the sun. The other villages represent municipalities that are found bordering forest land where Ogiek had been evicted from before being resettled at Ndungulu. See details on Table S1 in Supplementary Materials for this article.

19 This report was published before the establishment of county system of local governance [47]. The former Uasin Gishu district and its environs is now referred to as Uasin Gishu County.

20 Ol'leinguse is a Maasai name.

21 Uasin Gishu is a Maasai name. The area was inhabited by Maasai before the colonial period.

22 The 2009 Report of the Prime Minister's Taskforce on the Conservation of the Mau Forest complex gives a figure of 788.3 hectares as the land given to Ogiek, while NEMA report gives it as 740 hectares.

23 According to the Complainants' Submissions on the Merits, Court Document submitted to the African Court on Human Rights and Peoples Rights. It states that the Ogiek from Kipkurere were evicted in 1986 and forced to live in a small village Ngatipkong. This was part of the evidence used by the Ogiek "complainants" in court proceedings for the African Commission on Human Rights and Peoples Rights Vs Republic of Kenya. Communication No. 006/2012. Which helped them win the case on 26 May 2017. http:/ / minorityrights.org/wp-content/uploads/2015/03/Final-MRG-merits-submissions-pdf.pdf 


\subsection{Description of Study Area-Kamuyu}

Kamuyu co-operative farm, as highlighted in Figure 2, is officially registered as (Lainguse/Kiptenga Block 1 and 2) at the Ministry of Lands and settlements. There are three villages namely; Forest, Mbarakira and Njabini. Those who live in "Forest" neighbor the Matharu forest. Those who live in Mbarakira village say that there was a dense woodland of mbarakira trees that were cleared to make way for settlements. Mbarakira is the Kikuyu name for trychocladus ellipticus, an indigenous tree that grows in the Aberdare range forest and mainly along waterways [50]. Those that live in Njabini are mainly immigrants from Njabini municipality in Nyandarua County, which is a former homeland for Kikuyu.

As an elder shareholder described ... "At the dawn of independence in 1965, a group of 233 Kikuyus and 7 Kalenjin from the Nandi sub group bought the Kamuyu land that was about 6000 acres. However, after the land clashes of 1992, the 7 Kalenjin were forced to leave and their land bought from them. The 1965 land deal was a tripartite agreement brokered between the lending Bank, the co-operative and DC MacLeod, a white British colonial settler. The Kikuyu buyers nicknamed him "gichaga" because he used to quarrel with everybody. Some called him 'Kiguru' because he walked with a limp. The farm was sold at 1,000 Kenya shillings per share including the farm equipment. At the time, Kamuyu was formed, the Kikuyu were rearing pigs, poultry and cows as common investment. All members were entitled to a maximum of 3 acres for personal use. The rest was used communally and the proceeds re-invested through their co-operative committee to offset the bank loan that was used to purchase the land." Interview with a 75-year-old male shareholder of the Kamuyu Cooperative society.

The Kamuyu name unites these Kikuyu shareholders. Kamuyu is adopted from a municipality found in Nyeri, a former homeland of the Kikuyu. Some of the founders of Kamuyu farm were former Mau Mau freedom fighters from Nyeri who had been jailed in Manyani and Naivasha for long and when they returned to their homelands in Nyeri, their land had been given to sympathisers ${ }^{24}$ of the colonial government [6], p. 242. Some ex-Mau Mau, who were well adjusted to forest husbandry had obtained jobs as forest wardens in the government ministry at the dawn of independence [51]. Another bulk of Kikuyu settlers, mainly from an area called Njabini in Kinangop constituency of Nyandarua County, had been plantation workers earning a living from planting pyrethrum or coffee in the white highlands occupied by British settlers.

"After purchasing the farm from the white owner in 1965, the members of Kamuyu Co-operative farm decided to demarcate the land in 1980's after the bank loan was settled. That marked the end of community activities such as planting maize and pyrethrum. Before demarcation every member had a share of 3 acre each and the rest was for the society, afterwards, every member was entitled to at least 7 acres. The good fertile areas were referred to as the 'special'. Those who obtained the sloppy areas were given 8 acres each, those who obtained the sloppy and rocky areas were given 9 acres each while those who obtained the sloppy, hilly and rocky areas which were had to plough were given 10 acres". Excerpt from key informant interview, Kamuyu Cooperative society.

\subsection{Study Design, Data Collection and Analysis}

This study utilized the ethnographic approach that included an array of qualitative methods to allow for in-depth long-term exploration of the study subject. A total of 47 in-depth interviews, 13 key informant interviews, participant observation and 9 focus group discussions were carried out intermittently over a total of 2 years between 2012 and 2017 in the study area. The in-depth interviews

24 Rich and educated Kikuyu men were recruited as surveyors and clerks, giving them some leverage in the land consolidation program. For instance, collaborators tended to favor people who had supported the government while discriminating against Mau Mau fighters and their sympathizers when allocating land. [6], p. 242. 
were comprised of Ogiek, Kalenjin and Kikuyu. The key informant interviews targeted experts on land issues while the focus groups were comprised of both men and women from the three communities. In each case study, one FGD was held jointly (men and women). The rest separately convened either men or women.

Purposive and convenience sampling were employed in the selection of the study participants. The communities were selected based on firstly, the conflict that has been prevalent in the area of Uasin Gishu, Rift Valley during elections periods. A second criteria that was used for selection was based on the predominance of agriculture as an economic activity (maize, pyrethrum and wheat farming) in Uasin Gishu. Thirdly, was their willingness to participate in the study and their geographical accessibility. The qualitative data from the interviews and focus group discussions were transcribed, coded and analyzed thematically. Observations documented as field notes were also analyzed to complement the study findings.

\subsection{Study Limitation}

The findings are not to be used to generalize ${ }^{25}$ the situation of ethnic conflict in Rift Valley as homogenous rather, some aspects were singled out being specific to different categories of ethnic groups depending on (i) the pre-colonial land tenure systems and (ii) current landownership patterns. For this research, the transcripts from interviews and focus group discussions are detailed ${ }^{26}$.

\section{Findings and Discussions}

This section highlights findings anchored on the neo-institutionalism theory to highlight the institutions and changes faced by the Ogiek as actors in navigating the formal and informal agrarian reform institutions in gaining ownership to their ancestral forest land in Kenya [29]. According to the authors of [13], p. 9, there are always competing institutions; those developed by the government, and are categorized as (formal) and those embedded within the culture of the local community (informal institutions) [13]". Institutional settings both formal (Chief's office) and informal (norms and values of Kikuyu, Kalenjin and Ogiek) around Mau Forest, play a major role in land ownership and redistribution. For this study, these 'rules of the game' are characterized by the following: (i) Devolution, land reforms and the role of National Land Commission (NLC), (ii) The role of the assistant Chief's office in the adjudication and arbitration of "distress" land sales, (iii) Contestation of traditional versus modern ways of sustaining Ogiek livelihoods (Ogiek, assistant Chief's office and NGOs), (iv) Contestation of access and use of Mau Forest between Ogiek and Kenya Forest Service, and lastly (v) Resolving land issues in an enabling political environment; the Kikuyu approach. The following section will elaborate on the aforementioned "institutional settings".

\subsection{Devolution, Land Reforms and the role of the National Land Commission (NLC)}

Institutional restructuring for land reform, according to Boone et al. (2016, p. 1), has been realized through the establishment of the National Land Commission ${ }^{27}$, which has been devolved at county level to, Environment and Land court, as well as the County Land Management Boards [52]. This is a welcome step in adjudication and arbitration of land matters in conflict areas such as Rift Valley. The challenge remains in the (i) cost of seeking adjudication and (ii) ethnic representation at the

25 Yin (2003, pp. 10-11) states that the second limitation with case studies is that they provide little basis for scientific generalization. A question often posed is "How can you generalize from a single case?" However, Yin states that, as with experiments and surveys, case studies are generalizable to theoretical propositions and not to populations or universes [48].

26 The third limitation of case studies, according to Yin, is that they take too long and result in massive unreadable documents. This is because of ethnographic and participant observation methods involved. However, this all depends on the timeframe of the investigator and the aims and objectives of the study [48], pp. 10-11.

27 Land Control Boards are now been abolished since the establishment of the National Land Commission (NLC) in 2012. However, the NLC will set up new land boards committees at local level that preside over all land matters, that will include the one-third representation by women as required by the new constitution. 
executive board level. For example, the Land Management Board (LMB) for Uasin Gishu County has offices in the urban town of Eldoret. Those who live in the rural farming areas have to incur transport costs and additional court fees when seeking redress in Eldoret.

For this study, the issue of ethnicity and ethnic groupings is important. One may argue that a precedent may have been set in promoting ethnic bias in the selection of county level officials for land administrative structures such as land committees. For example, Uasin Gishu County has several other ethnic groups such as Kikuyu and Ogiek. Yet on 6 November 2014, six members (3 men and 3 women all from Kalenjin ethnic group) were sworn in as the new Land Management Board (LMB) for Uasin Gishu County ${ }^{28}$. However, the LMBs were later revoked by the Land Laws (Amendments) Act, of 2016. A major improvement that has been realized is that there is gender equality on the land boards and this has created an enabling environment for women to bring forward their land adjudication, registration and ownership issues. This is a step forward from the old structure of land boards ${ }^{29}$ which were often male dominated and had a woman who doubled as the secretary and tea girl ${ }^{30}$.

In addition, the Kenyan government has made progress in creating an enabling legal environment for communities interested in registering land under communal land tenure, through the introduction of the Community Land Act (CLA) ${ }^{31}$ in October 2016. According to the CLA, community land will be held under customary, leasehold and freehold tenure systems. Customary ${ }^{32}$ law will be used in the adjudication and administration of the community land. However, at national level, there are still some challenges. A Communal Land Registrar has not been appointed. In addition, the regulations for the Communal Land Act which were formally announced as being available in 2017, have not yet been made available [21]. One may argue that, at local level, clan-based community land certificates are available and viable under the Community Land Act of 2016 and it is up to the community to decide how to define its community land area. However, findings from the research area show that despite a sound legal framework, sometimes dominant communities can use the land policies in unlawful ways and reverse legal gains. This is evidenced in the informal land sales occurring on Ndungulu settlement scheme highlighted below.

\subsection{The Role of the Assistant Chief's Office in Adjudicating and Arbitrating over "Distress" Land Sales}

The Ogiek in Ndungulu settlement scheme have found an innovative way to raise money to maintain their daily existence. Despite the fact that they (Ogiek) were resettled by the government on this land, they now circumvent the state machinery such as lawyers, land surveyors and administrative officers, to enter into binding land sale agreements irrespective of the formal law. The chief's office is a formal provincial administrative institution and the Chief is appointed from central government ${ }^{33}$.

28 http://uasingishu.go.ke/.

29 In most communities in Kenya, land adjudicators and arbitrators were men. This pattern was mirrored in the structure of land committee and board members. The justification used for a formal institution was simple-women's participation in this process has been almost non-existent in the past. 'Customary law' was used as the reference point [53], p. 39.

30 When the researcher began data collection in 2012, the Kesses Land Board which had jurisdiction over the Ol'leinguse location where the case studies are situated, was all male. The members stated that is was "gender compliant" because the secretary Ms Rael Lamai, was always present at meetings to take notes and to kindly serve them with tea.

31 This was an improvement of the Trust land Act, which was more attune to the governance of ranches by pastoralists. The CLA is envisaged as a big win for communities which value the communal land tenure systems. In the CLA, "Community" has been defined to mean a consciously distinct and organized group of users of community land who are citizens of Kenya and share any of the following attributes: common ancestry, similar culture or unique mode of livelihood; socioeconomic or other similar common interest; geographical space; ecological space; or ethnicity. The constitution of a community is therefore not limited to ethnic lines as is the case with the current practice. The reason for this new clause being that ancestral land claims would balkanize the country into ethnic enclaves.

32 The term "customary land rights" is defined to mean rights conferred by or derived from African customary law, customs or practices provided that such rights are not inconsistent with the Constitution or any written law.

33 Contrary to the arguments made by [9], pp. 64-68, on "neo-customary" land regimes in Africa, the context is different for $\mathrm{Ol}^{\prime}$ leinguse location. Unlike other countries such as Ghana (Affou et al., 2007) [54], and South Africa (Rangan and Gilmartin 2002) [55], whose ethnic groups have well defined structures of chieftaincies, the ethnic groups in the area of Uasin Gishu did not have chiefs as land administrators. This position was adopted from the colonial period, by the post-colonial government. 
However, the assistant chief $^{34}$ is a local appointee who is voted into office by the local population. The research study established that the Ogiek are able to make written agreements through the office of the assistant chief, with non-Ogiek for the sale of small portions (known as points) of land. These Non-Ogiek include Tugen, Kipsigis, Nandi and Keiyo from neighboring counties of Baringo, Kericho, Nandi and Elgeyo Marakwet respectively. The same pattern has been documented about the Ogiek settled on Tinet [56] settlement scheme. As described by the Assistant Chief of Ol'leinguse location "I do not like to see Ogiek selling off land and becoming poorer every day, however they voluntary come to me and request me to adjudicate over these land sales between them and non-Ogiek because it is cheaper for them to ask for my services rather than engaging a land surveyor" (KII, assistant Chief, Ol'leinguse). The sales are precarious because the Ogiek do not have tittle deeds for their land. These distress land sales often occur whenever they are faced with a financial problem. In addition, one may argue that these sales occur because the settlement scheme is not under communal land tenure, therefore the community does not have an 'umbrella' association that could mitigate poverty and prevent these kinds of sales. Which is why the 2016 Communal Land Act is a welcome step.

Distress land sales take place under pressure of poverty, usually with a likely long-term negative effect on household economy. Many Ogiek households were more engaged in "buying" and "selling" of small portions of land such as a tenth of an acre which is called a "point" and would cost 15,000 Kenya shillings. Delville, (2003, p. 91) [57] who observed the same in West Africa calls this "institutional innovation". He argues that it occurs because the land market has not harmonized the statutory law requirements with the needs of people in rural areas. The transaction costs for seeking legal justice when entering a land sale agreement are too high in comparison to the size of the land that is being acquired. These informal land sales are carried out notwithstanding that the Ogiek do not have tittle-deeds to the land [56].

The Ogiek who were settled between 1995 and 1997 are eligible to apply for a tittle deed for the whole 740-acre farm but not individually. Therefore, to be able to pay, they must collectively raise 1.5 million Kenya shillings. So far, by 2017, a total of 960,000 shillings has been collected. As explained by a Kalenjin couple who have bought land from Ogiek, "the Ogiek are too poor to jointly raise that fee for title-deed registration. If it was up to us (non-Ogiek) we can raise money through our other agricultural activities in Moiben or Nandi." Therefore, the study noted that, the Kalenjin have alternative sources of income unlike the Ogiek. For example, some of them had their "ancestral" 35 land elsewhere which could provide them with the capital which they use to purchase the land from Ogiek.

These distress land sales have implications on security of land tenure for other household members such as wives and children. These kinds of land sales are organized locally and often finalized in drinking places, usually by men. Women do not have control over these sales and frequently do not know about them until they see their husbands with money. During focus group discussions, women voiced their concerns about these land sales, but are hesitant to confront their husbands, for fear of beatings at home.

\subsection{Contestation of Maintaining Traditional Versus Modern Livelihoods (Ogiek, Chief's Office and NGOs)}

Another social economic activity that highlights how dominant ethnic communities may override the interest of minority groups in settlement areas is evidenced through a beekeeping project captured in Figure 3 . In 2012, The United States Agency for International Aid (USAID) provided a grant of 1000 US dollars through Mercy ${ }^{36}$ Corps, to enable the Ndungulu settlement peace ${ }^{37}$ committee to purchase the necessary

34 At the time of the interview in 2012, the Assistant Chief, a Kalenjin, had held this position since 1989 and was relied upon as the "institutional memory" for the land sales.

35 Sub ethnic community of Nandi are from Nandi county, the Kipsigis are from Kericho county, Tugen are from Baringo county and Keiyo from Elgeyo Marakwet counties.

36 Mercy corps has many projects in Uasin gishu on peace. There are passionfruit for peace in Olare that is in the north, then goats for peace in Kesses, then in Cheptiret there is a rehabilitated market for peace, a poultry project in Chegeiya and a bridge project in Matharu.

37 Information derived from a key informant interview in 2012, with a Peace Monitor at the Ministry of Internal affairs, District Commissioners office, Uasin Gishu county, Eldoret town. 
beehives and harvesting equipment for the project. After the post-election violence of 2007, peace committees were established in ethnic sensitive areas to implement the alternative dispute resolution mechanism at grass root level. The choice for selecting a beekeeping project by the peace committee for residents of Ndungulu was based on the fact that the traditional way of beekeeping is seen as a forest-fire hazard by Kenya Forest Service authorities. When the researcher visited the area in 2017, the project had been abandoned and the Ogiek elders referred to it as "hiyo mzinga za watu wa agriculture" in Kiswahili, which can be translated as "those beehives for agriculture extension workers".

A repetition of mismatching the modern versus traditional economic livelihood approaches of Ogiek community may likely occur in future because of two recent historic events. Firstly, the international court ruling of May 2017 Ogiek. Secondly, the loopholes in the Community Land Act (CLA) 2016. The implications of these two issues are discussed below.

On 26 May 2017, a court ruling ${ }^{38}$ by the African Court for Human and Peoples' Rights (ACHPR) located in Arusha, Tanzania declared that the Ogiek have a right to gain ownership to their ancestral land. According to Alden Wily (2018, p. 666) [21], the ACHPR found that the Kenya Government had violated the rights of the Ogiek under various Articles of the African charter. Further, that the Mau Ogiek had occupied the land since time immemorial and were entitled to occupy and use their lands. While the court acknowledged that this possession might be restricted for a public purpose, it found no evidence that the Ogiek presence was the main cause of severe environmental degradation and encroachment. The legal challenge here is that the same institution that took away the forest land rights from Ogiek by gazetting all forest land and mandating the Kenya forest service to manage it, is now expected to give back the land. Already, it has been observed through national media (Star) ${ }^{39}$ that the government is likely to compensate the Ogiek rather than restitute their ancestral land to them.

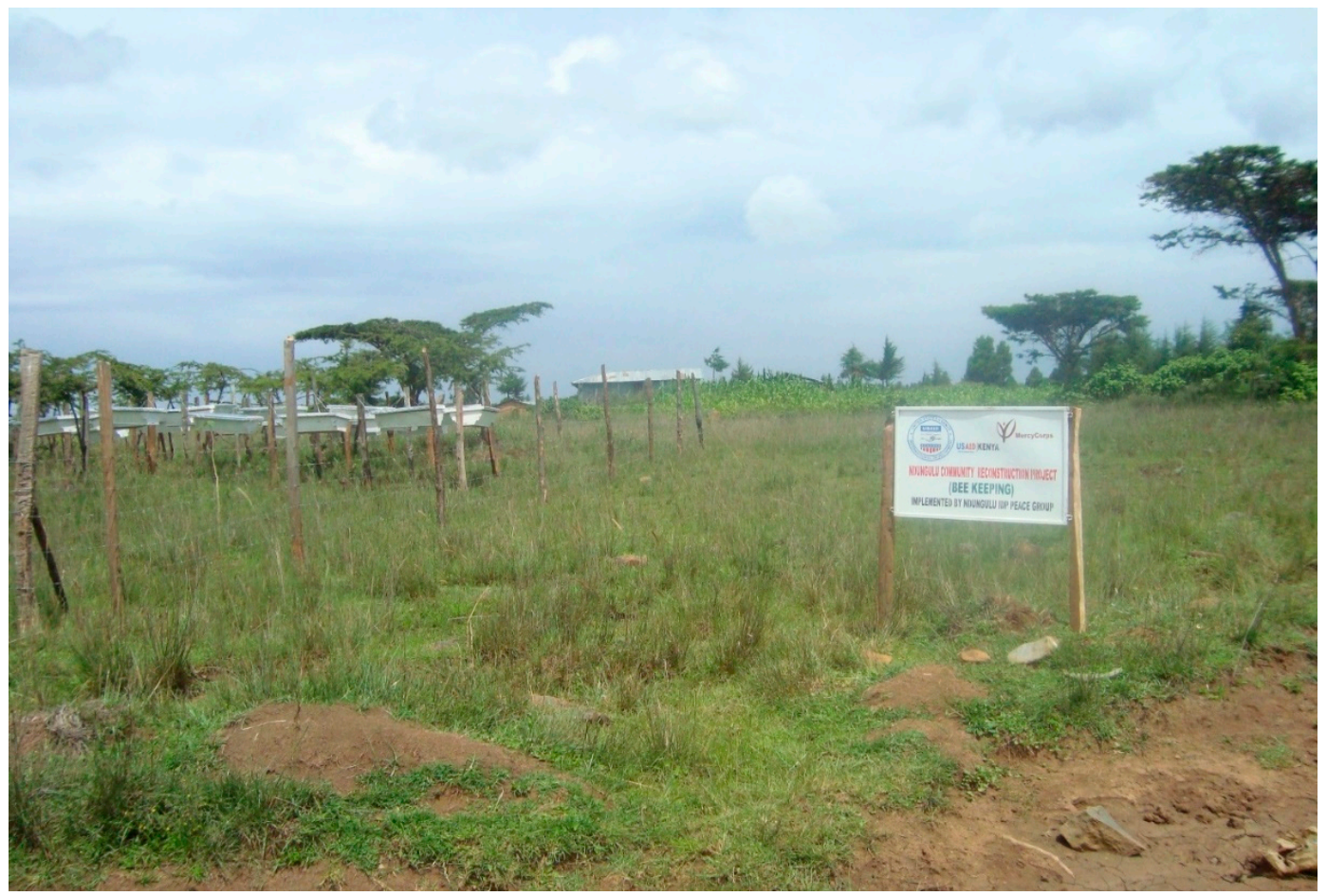

Figure 3. Bee-keeping ${ }^{40}$ project on Ndungulu settlement scheme.

40 Picture taken by Jemaiyo Chabeda.

38 http://en.africancourt.org/images/Cases/Judgment/Application\%20006-2012\%20-\%20African\%20Commission\%20on\% 20Human\%20and\%20Peoples\%E2\%80\%99\%20Rights\%20v.\%20the\%20Republic\%20of\%20Kenya.pdf.

39 The Star interview: We've restored 850k hectares of degraded forests by involving communities-PS. https://www.the-star. co.ke/news/2017/06/22/interview-weve-restored-850k-hectares-of-degraded-forests-by-involving_c1579273. 
As much as the enactment of the 2016 Community Land Act is a welcome step for communities that are interested in communal land tenure, there are some legal loopholes that can affect minorities such as Ogiek. For example, at County level [21], p. 669, points out that, "Draft regulations under the Act fail to specify the responsibility of counties to investigate which communities are affected by a development and to insist upon compensation through procedures involving those communities from the outset". At local level, there is a risk that this pattern of sidelining minorities such as Ogiek, will continue within the context of Community Land Management Committees proposed through the Community Land Act. In the event that for the sake of a "development" project, the county governments propose that Ogiek enter into communal land ownership agreements with other communities such as the neighboring Kalenjin, they may eventually be dominated at the executive level such as in the Community Land Management committees (CLMCs). In addition, lack of autonomy within land management institutions might give rise to further marginalisation if the membership is skewed towards a particular ethnic group.

To maximize on the use of the Mau forest for traditional apicultural practices, there needs to be a horizontal transfer of knowledge (between Ogiek east of Mau forest and Ogiek west of Mau forest) about marketing networks. The Ogiek in East Mau Forest living in Marishoni, have well-defined networks of marketing their honey ${ }^{41}$. However, the Ogiek in Ndungulu sell their honey in small quantities to herbalists and beer makers locally. They do not have enough access to forest land to produce as much honey as their counterparts. There are already global markets in place through organizations such as slow food ${ }^{42}$ which the Ogiek can tap into. One may argue that, through such networks, poverty levels can be decreased among the Ogiek and prevent them from carrying out distress land sales.

\subsection{Contestation of Access and Use of Mau Forest (between Ogiek and Kenya Forest Service)}

The Ogiek owes its international privileged identity as an "indigenous" community, see [58], to its specific materiality of beekeeping. In proving that Ogiek are out to protect the forests rather than exploit the resource, a report (2012) ${ }^{43}$ was submitted to the African Court for Human and Peoples Rights. In it, there are various indicators that were used to point how Ogiek took "extra care" in the way they harvest, store and use honey. The main focus was on the way the Ogiek apply their indigenous knowledge, see Semali and Kincheloe, 1999 [59], of the forest to sustain livelihoods in their various government sanctioned settlement schemes, such as Ogiek residing west of Mau Forest i.e., those in my case study of Ndungulu settlement. The Ogiek want to claim up to 30 distinct community land areas over the Mau forest ecosystem. They have been able to identify these areas through an intensive territorial mapping exercise that began through the $\mathrm{KIFCON}^{44}$ project and recently through the compilation of an atlas of Ogiek peoples' ancestral territories (OPAT) ${ }^{45}$.

However, the Ogiek have a tense relationship with the Kenya Forest Service whom they view as limiting their access to their ancestral land i.e., forests, due to the introduction of community forest associations. In many countries in sub-Saharan Africa, participatory forest management or

41 https://necofakenya.wordpress.com/2012/11/16/socio-economic-development-traditional-knowledge-andbiodiversity-protection-of-the-ogiek-community-mariashoni/.

42 https://www.slowfood.com/new-dawn-ogiek/.

43 According to the Complainants' Submissions on the Merits, Court Document submitted to the African Court on Human Rights and Peoples Rights. This was part of the evidence used by the Ogiek "complainants" in court proceedings for the African Commission on Human Rights and Peoples Rights Vs Republic of Kenya. Communication No.006/2012. Which helped them win the case on 26 May 2017.

44 Kenya Indigenous Forest Conservation Project (KIFCON) 1992. A consideration of strategies for settlement of the Okiek Ndorobo of South west Mau Forest, Ministry of Environment and Tourism, Nairobi.

45 An Ogiek People's Ancestry and Territories (OPAT) Atlas for the Ogiek of Eastern Mau was published in 2011. With help from the discussions among Ogiek community members, the University of Bern together with their partners in an organization called Kenya Environmental Research Mapping and Information Systems in Africa (ERMIS), determined which critical features (e.g., hills, rivers, cultural areas), are considered as Ogiek clan territory. 
community based natural resource management is a concept that encouraged by governments as a way for communities that reside next to forest areas to access the forest. According to Koech et al. [60], there are 11 community forest associations registered in Mau Forest. The process of applying for registration requires that the members have to have some level of education and money to pay for the fees which ranges between 2000 and 5000 Kenya shillings per person [60].

Another participatory forest management approach that was introduced by the government after the post-election violence of $2007 / 2008$ is the shamba system. The word shamba, means garden in Kiswahili language. This system of farming is originally known as taungya, see [61]. Witcomb and Doward [62] argue that in theory, it is "beneficial" to local people and the government. However, in practice, the shamba system only relegates the farmers to a category of "forest users" who have no real say in forest management. This results in the limited participation of the 'forest user' because the government retains the power over 'forest user rights' [62].

After the 2007 post-election violence, the Kenya Forest Service introduced the idea of "shamba" system as a way to prevent 'idleness' and 'mischief' amongst youth, see Van Stapele, 2010 [63], from some ethnic communities. This was done in selected areas such as around Mount Kenya and Mau Forest in what Mathu and Ng'ethe $(2011$, p. 16) call the "Plantation Establishment and Livelihood Improvement Scheme" (PELIS) project [64]. The requirement was that these "shamba" farmers had to be part of a community forest association (CFA), in response to the policies by global organizations such as UN REDD.

Overall, this study by [64], established that this set of "forest user rights" as defined by the Kenya Forest service do not give details on the permitted social practices for those gaining access to the resource. In the case of Ogiek, the access to the forest is mainly for apiculture and obtaining indigenous herbal medicine. The shamba system rules are set at the operative level of Kenya Forest Service (KFS) while there are rules set up at the collective choice level (community level). One may argue that, benefits from these interactions at the inter-community level (between KFS and communities) and intra-community level (between the various ethnic group; Ogiek, Kikuyu and Kalenjin forest users), are realized when the rules remain consistent. However, findings from the case study show that these rules are skewed in favour of the state institutions such as KFS, who wield the power of access and ownership of the Mau Forest. In addition, dominant ethnic communities (Kikuyu and Kalenjin make ultimate decisions on the priorities for forest use e.g., charcoal making as highlighted below.

\begin{abstract}
"We have some "shamba farmers" on Ndungulu farm who had been allowed to cultivate on half acre each in the Sereng'onik section of Mau forest. This is actually a community forest association (CFA), called Leinguse peace and conflict management group. It has 72 members from Ogiek, Kikuyu and Kalenjin communities who are both female and male. What stood out for me was that out of the 72 members, only 11 are Ogiek. The Ogiek have no money to afford to pay for membership in such associations. The Ogiek are not interested in the charcoal business like the Kalenjin and Kikuyu. The dorobo (Ogiek) are not interested because they like to brew alcohol and are lazy. In fact, the Ogiek who are registered do so because it is the only means through which the Kenya Forest Service allows them to harvest honey using their traditional beehives. The forest is also important for carrying out circumcision ceremonies." Interview with Chairperson, Leinguse peace and conflict management group.
\end{abstract}

Furthermore, on Kamuyu farm and Ndungulu settlement scheme, the proximity to the surrounding forests of Nabkoi, Kapilat and Cenghalo has enabled the Kikuyu and Kalenjin women and men to 'tap' into the business of trading charcoal and firewood. When the research was conducted in 2012, the Kalenjin women stated that they were able to buy a license issued by Kenya Forest Service to cut firewood from the forest at 100 shillings. However, by 2013, the KFS had stopped issuing licenses to the CFAs. The research study established that the Ogiek who do not participate in the charcoal and firewood business are considered as lazy. In contrast, the Ogiek insist that they are completely against 
this charcoal and firewood business. They did not see themselves as lazy, on the contrary, they view the other dominant ethnic communities as having no desire to protect the forest.

This 'laziness' narrative is perpetuated by the Kalenjin and Kikuyu communities which may see themselves as "progressive" because both have been represented at top political echelons e.g., presidency and at the local government position of Chief and Assistant Chief. The dominant ethnic groups may have subconsciously developed a negative attitude towards smaller Ogiek because of their lack of interest in adapting to their income generating activities, such as charcoal and prefer to stick to their traditional livelihood approaches. This attitude by the dominant ethnic communities correlates with the social dominance orientation theories. In addition, the level of education attained by the Ogiek in Ndungulu is comparably lower to that attained by Kalenjin and Kikuyu.

\subsection{Resolving Land Issues in an Enabling Political Environment: The Kikuyu Approach}

Case of Legal Intervention by Hon. Martha Karua, Former Minister of Justice and Constitutional Affairs

In contrast to the situation of Ogiek who have had to seek legal representation at international level for unresolved land issues dating to precolonial time, the Kikuyu who faced land dispossession from British colonial settlers were aided by the President Jomo Kenyatta, the first post-colonial president of Kenya. His tenure in office enabled the Kikuyu to own land in other parts outside their ancestral homeland. His political mantra was "harambee" meaning 'pulling together'. For land reform policies, his philosophy was used in reference to pulling together finances for the formation of cooperatives and land buying companies to acquire land in Rift Valley. President Kenyatta resettled many members of the Kikuyu ethnic community in Rift Valley following the post-independence land redistribution plan. As shown in Figure 4, they migrated from Nyandarua and Nyeri to Uasin Gishu.

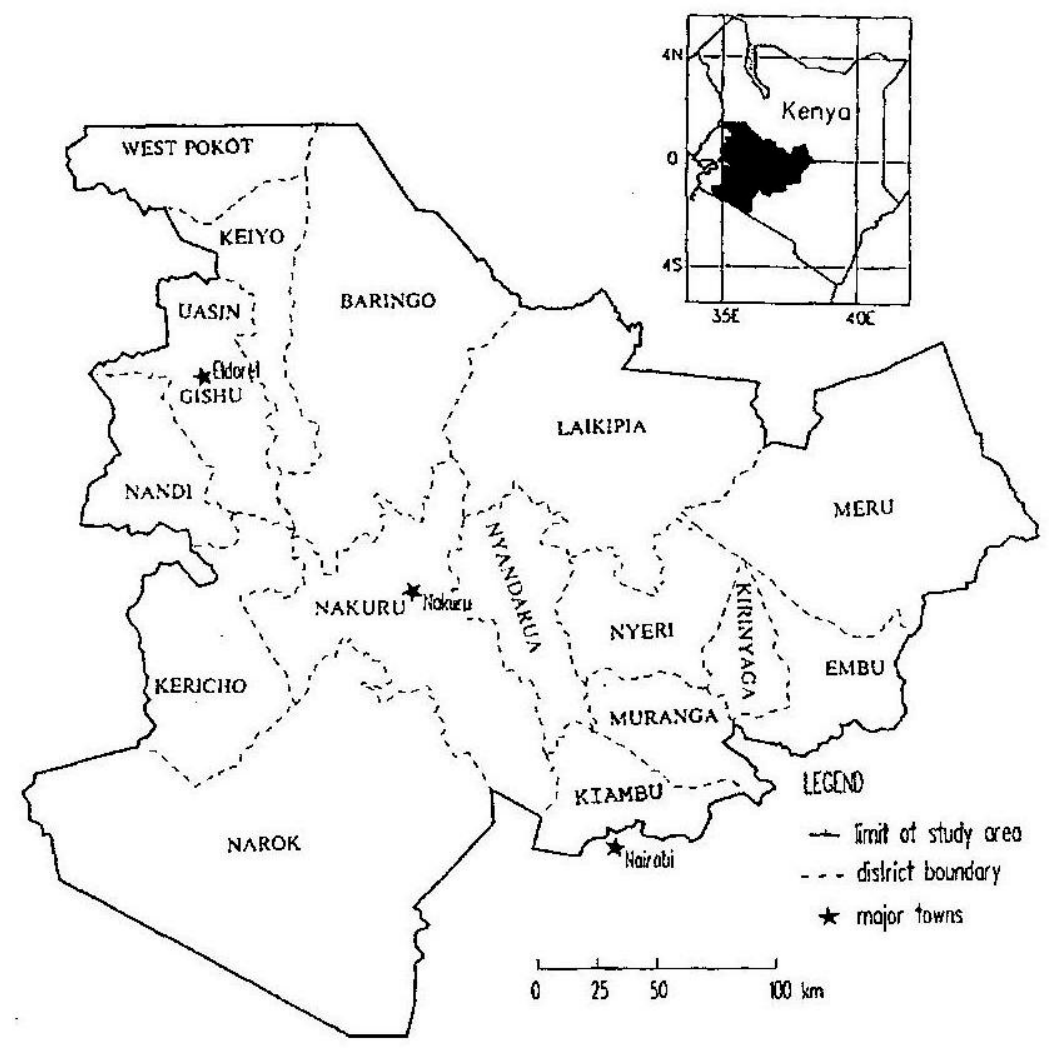

Figure 4. Map showing homelands of the Kikuyu immigrants on Kamuyu farm from Nyandarua and Nyeri (Sourced from [65]). 
In post-independence Kenya, large tracts of land officially registered as settlement schemes ${ }^{46}$, see [66], and were excised off from Government forests to resettle squatters and Mau war veterans [67]. These included the 'million acre schemes' and the "haraka" settlement schemes in Rift Valley $[7,8]$. In addition, Kanyinga (2009, pp.108-198) states that by early 2004, there were about 418 settlement schemes in the country, 154 or 37 percent were in Rift Valley, of these one third were owned by Kikuyu the so-called "immigrant guests" [66]. Furthermore, a "class bias was evident in these programs because those people with the ability to pay 10 percent deposit for the cost of the plots and operating capital got larger plots, these were the elite and salaried" [66].

The interview excerpt illustrates how and why the Kikuyu living in an area with recurrent ethnic conflict have managed to resolve their land ownership issues:

"Mostly the Kamuyu cooperative committee resolves the cases we especially land disputes cases. However, big cases are handled by our Kikuyu politicians. For example, during the time we were doing demarcation a government surveyor was employed to do the demarcation, previously it was done by a private surveyor and that was back in 1980. The government surveyor was brought to come and put clear boundaries for issuance of title deeds. The surveyor was not good in his work and he cut out some portions from an owner and allocated them to another person. People started complaining and they started so many cases of that improper land allocation. When I became chairman in 2004, the demarcation issue was the first case I started handling. We were happy because Mwai Kibaki (Kikuyu ethnicity) was president and things were better for Kikuyus. Some of the committee members and I went to Nairobi and met Martha Karua (the then Minister of Justice and constitutional affairs) who assigned us a lawyer to oversee that case. Before the case could pick up came the 2007 post-election violence. When this confusion ended I went back to her office but she was transferred from that ministry to another. She is a good Kikuyu politician, because she still resolved our matter even though she had moved."

\section{(KII, Chairman, Kamuyu Cooperative Farm)}

There are two elements at play here, the first is the Kamuyu-Kikuyu community's mistrust in immediate local land governance structures, but have confidence in national governance structures which are dominated by politicians from the Kikuyu ethnic community. This can be attributed to their status as "immigrant guests". It should be noted that at the time of this interview in 2012, transport costs from Burnt Forest to Nairobi to meet with Martha Karua were marginally higher than those from Burnt forest to Eldoret to meet with area MP Peris Simam, yet the Kamuyu committee preferred to meet with Ms Karua. In this situation, the committee of Kamuyu cooperative society approach Martha Karua (Kikuyu ethnic group) who was then the member of parliament for Gichugu (a constituency in Central province of Kenya) as well as a cabinet minister, for assistance in resolving a land issue for them in Uasin Gishu rather than approaching their own member of Parliament Ms Peris Simam who is from the Kalenjin ethnic group. This builds on my earlier arguments about devolution of the National Land Commission and the ethnic bias in selecting members of the land boards. This type of selectivity may oblige ethnic groups to seek redress on their land issues through their own networks e.g., Kikuyu politicians because they are trustworthy.

The second element at play here is that Martha Karua takes up this case and even pays a lawyer to handle it. Such patron-client relationships are largely motivated by one's sense of commitment to the ethnic community. Martha Karua hires a lawyer for the Kamuyu committee even if they are not from her constituency. She reinforces their trust in "belonging" to the Kikuyu community even though they have migrated and live far from the so-called Kikuyu homelands in central province.

46 According to Kanyinga, 1989, pp. 108-109 [66], "the skewed nature of the policy in favor of the Kikuyu was an issue of concern. Some of the settlements schemes were designed to satisfy the Kikuyu land hunger because they-Kikuyu, had the organization to destabilize the structure of landownership and the economy." 


\section{Discussions}

The colonial and post-colonial governments both supported policies that gazetted forests putting them under management of government. This move affected the livelihoods of indigenous forest dwellers such as the Ogiek were affected [16,44]. Although the government measures (both colonial and post-colonial) to protect the forest, may have emerged out of well-founded global concepts of environmental protection, it swiftly changed from saving the forests to violent eviction of Ogiek [19]. An occurrence that Alden Wily (2018) has referred to as "green grabbing" [21].

In the Rift Valley region of Kenya, the value of land around Mau Forest has increased over the years because of the favorable climatic conditions and also proximity to a natural resource. That is why the prevalence of "distress land sales" between Ogiek and non-Ogiek is highlighted in this article. The Mau forest as a common pool resource, has been exploited by those with stronger bargaining power such as politicians, local leaders and dominant ethnic groups in several ways. The first, is to harvest wood and convert it into charcoal, which is a lucrative business conducted between rural and urban areas. Secondly, to exploit the trees for timber used as building materials. In addition, over the years, companies such as Timsales and Raiply which have political interests have harvested trees to supply to the Webuye paper mill $[19,20]$. Third reason is that, part of the resource has been sold off to politicians who then convert the forest land into large-scale farms that specialize in cash crops such as wheat and maize. In addition, to purchasing land near a rich common pool resource such as Mau Forest, other non-Ogiek are eager to use the new infrastructure that has been put in place (better road network and rural electrification that started in 2012). This changing state of infrastructure is driving the prices of land further up.

This issue of "distress land sales" brings forward the implications of compensating a community with a tenure framework that is individualized rather than "communal land tenure". The fact that some Ogiek have chosen to sell land shows the social reality; that economic needs supersede cultural ties. The Ogiek who sell land may be faced with an economic crisis at household level and choose to sell off land and lose their social ties with their fellow Ogiek. One may argue that, in a homogenous (ethnic) communal land tenure setting the community may be able to offer an alternative to this sort of economic setbacks. Hence, the enactment of the 2016 Communal Land Act is a welcome step in this regard. Secondly, the Ogiek, do not have a fallback ancestral home like their fellow Kalenjin cousins. The Ogiek land (Kipsangany and Kipkurerek) are now Gazetted Government forests therefore there is no extra source of capital to start economic activities. By contrast, the Kalenjin have ancestral land in Nandi, Elgeyo marakwet, Baringo and Kericho counties.

One cannot ignore the fact that the discourse on victimhood of Ogiek is straddled between human rights and freedom of culture. First, the proponents of the human rights advocate for individualization and "self" empowerment. The 're-turn' to customary practices are promoted as communitarian yet in practice, serve to benefit the patriarchs, more so the senior men of the community. This is evidenced by the fact that women learn about "distress land sales" after the transaction has occurred. This issue is examined by Lesorogol (2009) in her study of privatization of Siambu ranch among the Samburu community in Kenya [68]. Secondly, proponents of the freedom of culture, advocate for the protection and promotion of cultural practices that are perceived to maintain communal harmony. In addition, the advocates for the rights for indigenous groups such as Ogiek, advocate for the freedom of culture and ancestral right to forest land, a move that has not been fully embraced by the government and associated land administration institutions.

\section{Conclusions and Recommendations}

The governance of Mau Forest that borders the case study of Ndungulu in Burnt Forest area, shows how the different communities interact differently with the forest landscape. The Kalenjin and the Kikuyu value the forest for charcoal, timber harvesting, and firewood for household use. The Ogiek on the other hand associate the forest with their cultural values such as bee keeping, harvesting medicinal plants, prayer shrines in remembrance of ancestors and also social memory. A new approach 
to forest governance is through the community-based associations. This approach is said to increase rights of local people to community forest management. However, findings from this study reveal the opposite.

The definition of "community" in the new Community Land Act (CLA) of 2016 has been modified to accommodate multiple users of community land who are citizens of Kenya and share any of the following attributes: common ancestry, similar culture or unique mode of livelihood. This may be progressive in the fight against ethnicity, on the contrary, it may water down the strength of customary land rights of minority ethnic groups seeking to engage in joint agreements. Furthermore, in instances where there is ethnic heterogeneity in the management of communal land, this may give rise to hierarchy. This is because dominant groups such as Kalenjin may legally assert themselves in "communal land ownership spaces" with the indigenous groups' i.e., the Ogiek. In addition, the CLA, has introduced the Community Land Management Committees (CLMCs) which may replace the elder's council in adjudication of land matters. One may argue that, if Kalenjin sub groups dominate the management positions of these CLMCs, then decisions are bound to be skewed in favour of Kalenjin and not Ogiek. Overall, the restitution of land to this indigenous group seems an uphill task for the government.

The land policies that were successful in western countries may not be the answer for a 'one-size fits all' land reform project for African countries such as Kenya. This study showed that the attempts by the state to reconcile ethnic animosities between Kalenjin and Kikuyu in Rift Valley tends to distract the land reform process from the real issue; the plight of the Ogiek. This study demonstrates that beyond the household level, marginalized communities such as the Ogiek living on Ndungulu settlement scheme, are in competition with dominant ethnic communities in the politics around land redistribution.

Supplementary Materials: The following are available online at http:/ / www.mdpi.com/2073-445X/7/4/140/s1, Table S1: Ogiek Families Settled in 1996/1997 after the Land Clashes of 1992.

Author Contributions: J.C.-B. identified the research site, recruited the informants, collected and analyzed the data. J.C.-B. drafted the original manuscript and has been working closely with T.H. to review and edit the paper for submission to the journal of Land. T.H. followed up on the conceptualization of the study, data collection editing and reviewing of the manuscript.

Funding: The first part of this research was supported through the Swiss Government Excellence Scholarships for Foreign Students 2010-2011. The last part of the research received financial support from the Josephine de Karman scholarships (2017), administered by the University of Bern.

Acknowledgments: I acknowledge the study informants including members from Kikuyu, Kalenjin sub-groups and Ogiek in Ol'Leinguse location of Kesses Constituency who were part of this study. Your approval to carry out the study, hosting and engaging the researcher, participation and invaluable insights made this study possible. Thank you very much.

Conflicts of Interest: The authors declare no conflict of interest.

\section{References}

1. Kariuki, S. Can a botched land reform programme explain Kenya's political crisis? J. Afr. Elect. 2008, 7, 135-172.

2. Ogot, B.A.; Ochieng, W.R. Decolonisation and Independence in Kenya 1940-93; James Currey: London, UK, 1995; p. 271.

3. Okoth-Ogendo, H.W.O. Property systems and social organisation in Africa: An essay on the relative position of women under indigenous and received law. In The Individual under African Law: Proceedings of the First all-Africa Law Conference October 11-16, 1981; Takirambudde, P.N., Ed.; Royal Swazi Spa: Lobamba, Swaziland, 1982; pp. 47-55, 271.

4. Syagga, P. Public Land, Historical Land Injustices and the New Constitution; Constitution Working Paper No. 9; Society for International Development, Regal Press: Nairobi, Kenya, 2010.

5. Berman, B.; Lonsdale, J. Unhappy Valley: Conflict in Kenya and Africa Book One: State and Class; James Currey: London, UK, 1992. 
6. Sorrenson, M.P.K. Land Reform in the Kikuyu Country: A Study in Government Policy; Oxford University Press: Toronto, ON, Canada, 1967.

7. Harbeson, J.W. Land and the Quest for a Democratic State in Kenya: Bringing Citizens back in. Afr. Stud. Rev. 2012, 55, 15-30. [CrossRef]

8. Boone, C. Land conflict and distributive politics in Kenya. Afr. Stud. Rev. J. Afr. Stud. Assoc. 2012, 55, 75-103. [CrossRef]

9. Boone, C. Property and Political Order in Africa: Land Rights and the Structure of Politics; Cambridge University Press: New York, NY, USA, 2014.

10. Ntsebeza, L.; Hall, R. The Land Question in South Africa: The Challenge of Transformation and Redistribution; HSRC Press: Cape Town, South Africa, 2007.

11. Deutsch, J.-G.; Probst, P.; Schmidt, H. African Modernities: Entangled Meanings in Current Debate; Heinemann: Portsmouth, NH, USA, 2002.

12. Yeoman, G. High altitude forest conservation in relation to the Dorobo people. Kenya Past Present. 1993, 25, 31-35.

13. Haller, T. The Understanding of Institutions and Their Link to Resource Management from a New Institutionalism Perspective; Working Paper 1 NCCR North-South; University of Bern: Bern, Switzerland, 2007.

14. Kipkorir, B.E. People of Rift Valley; Evans Brothers: London, UK, 1978.

15. Lynch, G. "I Say to You": Ethnic Politics and Kalenjin of Kenya; University of Press: Chicago, IL, USA, 2011.

16. Blackburn, R. The Ogiek History Kenya before 1900. Master's Thesis, East African Publishing House Limited, Nairobi, Kenya, 1976.

17. Jenkins, S. Ethnicity, violence, and the immigrant-guest metaphor in Kenya. Afr. Aff. 2012, 111, 576-596. [CrossRef]

18. Kershaw, G. Mau Mau from Below; James Currey: London, UK; East Africa Educational Publishers: Nairobi, Kenya; Ohio University Press: Athens, OH, USA, 1997.

19. Kimaiyo, T.J. Ogiek Land Cases and Historical Injustices, 1902-2004; Ogiek Welfare Council: Nakuru, Kenya, 2004.

20. Sang, J. Supporting the Right of a Kenyan Indigenous Group; Ogiek Welfare Council Publishers: Nakuru, Kenya, 2002.

21. Alden Wily, L. Risks to the sanctity of community lands in Kenya. A critical assessment of new legislation with reference to forestlands. Land Use Policy 2018, 75, 661-672. [CrossRef]

22. Hodgson, D. Being Maasai, Becoming Indigenous. In Postcolonial Politics in a Neoliberal World; Indiana University Press: Bloomington, IN, USA, 2011.

23. Médard, C. Quelques clés pour démêler la crise kenyane: Spoliation, autochtonie et privatisation foncière. IFRA-Sables-d'olonne n.a. Cah. D'Afrique De L'Est 2008, 37, 81-98.

24. Kitching, G. Class and Economic Change in Kenya: The Making of an African Petit Bourgeoisie 1905-1970; Yale University Press: New Haven, CT, USA, 1980.

25. Haugerud, A. The Culture of Politics in Modern Kenya; Cambridge University Press: Cambridge, UK; New York, NY, USA, 1993.

26. Chauveau, J.P.; Cisse, S.; Colin, J.P.; Cotula, L.; Delville, P.L.; Neves, B.; Quan, J.; Toulmin, C. Changes in Customary Land Tenure Systems in Africa; Russel Press: Nottingham, UK, 2006.

27. Leakey, L.S.B. Mau Mau and the Kikuyu; Routledge Publishers: Oxon, UK, 1952.

28. Waller, R.D. Acceptees and Aliens: Kikuyu settlement in Masaailand. In Being Masaai: Ethnicity and Identity in East Africa; Spear, T., Waller, R.D., Eds.; James Currey Publishers: London, UK, 1993.

29. Joireman, S.F. Entrapment of Freedom: Enforcing Customary Property Rights Regimes in Common-law Africa. In The Future of African Customary Law; Fenrich, J., Galizzi, P., Higgins, T., Eds.; Cambridge University Press: Cambridge, UK, 2011; pp. 295-311.

30. Chanock, M. Law, Custom and Order. In The Colonial Experience in Malawi and Zambia; Cambridge University: Cambridge, UK, 1985.

31. Brubaker, R. Ethnicity without Groups; Harvard University Press: Cambridge, MA, USA; London, UK, 2004.

32. Rutten, M.M.E.; Owuor, S.O. Weapons of mass destruction: Land, ethnicity and the 2007 elections in Kenya. J. Contemp. Afr. Stud. 2009, 27, 305-324. [CrossRef]

33. Kagwanja, K. Courting genocide: Populism, ethno-nationalism and the informalisation of violence in Kenya's 2008 post-election crisis. J. Contemp. Afr. Stud. 2009, 27, 365-387. [CrossRef]

34. Steeves, J.S. Democracy unravelled in Kenya: Multi-party competition and ethnic targeting. Afr. Identities 2011, 9, 455-464. [CrossRef] 
35. Klopp, J. Can Moral Ethnicity Trump Political Tribalism? The Struggle for Land and Nation in Kenya. Afr. Stud. 2002, 61, 269-294. [CrossRef]

36. Ferrari, F.M.; Freudenthal, E.; Kenrick, J.; Mylne, A. The whakatane mechanism: Promoting justice in protected areas. Nomadic Peoples 2012, 16, 84-94.

37. Wolf, E. Ownership and Political Ecology. Anthr. Q. 1972, 45. [CrossRef]

38. Blaikie, P. The Political Economy of Soil Erosion in Developing Countries; Longman: London, UK, 1985.

39. Hershkovitz, L. Political Ecology and Environmental Management in the Loess Plateau, China. Hum. Ecol. 1993, 21, 327-353. [CrossRef]

40. Davis, S.H.; Wali, A. Indigenous land tenure and tropical forest management in Latin America. Ambio 1994, 23, 485-490.

41. Speranza, C.I.; Kiteme, B.; Ambenje, P.; Wiesmann, U.; Makali, S. Indigenous knowledge related to climate variability and change: Insights from droughts in semi-arid areas of former Makueni District, Kenya. Clim. Chang. 2010, 100, 295-315. [CrossRef]

42. Haller, T.; Galvin, M. Conclusion: Participation, Ideologies and Strategies: A Comparative new Institutionalist Analysis of Community Conservation. In People, Protected Areas and Global Change; Galvin, M., Haller, T., Eds.; Geographica Bernensia: Bern, Switzerland, 2008; Volume 3, pp. 507-549.

43. Branch, D.; Cheeseman, N.; Gardner, L. Our turn to eat: Politics in Kenya since 1950; Lit Verlag: Berlin, Germany, 2010.

44. Wachira, M.G. Vindicating Indigenous Peoples Land Rights in Kenya. Ph.D. Thesis, University of Pretoria, Pretoria, South Africa, 2008.

45. Ensminger, J. Anthropology and the New Institutionalism. J. Inst. Theor. Econ. 1998, 154, 1-2, 774-789.

46. Ensminger, J. Making a Market; Cambridge University Press: Cambridge, UK, 1992.

47. NEMA. National Environmental Management Report, NEMA 2009-2013; Ministry of Land and Mineral Resources: Uasin Gishu County, Kenya, 2009.

48. Yin, R. Case Study Research: Design and Methods; Sage Publications: London, UK, 2003.

49. The Kenya National Population Census; Kenya Bureau of Statistics: Nairobi, Kenya, 2009.

50. Nicholson, M.J.L. Soils and Land Use on the Northern Foothills of the Aberdare Range Kenya. Bachelor's Thesis, University of Aberdeen, Scotland, UK, 1976.

51. Maloba, O.W. Mau Mau and Kenya: An Analysis of a Peasant Revolt; James Currey: London, UK, 1998.

52. Boone, C.; Dyzenhaus, A.; Gargule, A.; Gateri, C.; Klopp, J.; Manji, A.; Ouma, S.; Owino, J.K. Land Politics under Kenya's New Constitution: Counties, Devolution, and the National Land Commission; Working Paper Series 2016; School of Economics: London, UK, 2016.

53. Pala, A.O. Women's Access to land and their role in agriculture and decision-making on the farm: Experiences of the Joluo of Kenya: Experiences of the Joluo of Kenya, Nairobi. J. East. Afr. Res. Dev. 1983, 13, 69-87.

54. Affou, S.; Crook, R.; Hammond, D.; Vanga, A.F.; Yeboah-Owusu, M. The Law, Legal Institutions and Protection of Land Rights in Ghana and Cote D'Ivoire: Developing a more Effective and Equitable System; Institute of Development Studies at the University of Sussex: Brighton, UK, 2007.

55. Rangan, H.; Gilmartin, M. Gender Traditional Authority and Politics of Rural Reform in South Africa. Dev. Chang. 2002, 33, 633-658. [CrossRef]

56. Mbote-Kameri, P.; Nyamu-Musembi, C. Mobility, Marginality and Tenure Transformation in Kenya. Explorations of Community Property rights in Law and Practice. Nomadic Peoples 2013, 17, 5-32.

57. Lavigne Delville, P. When farmers use "pieces of paper" to Record their land transactions in Francophone rural Africa: Insights into the Dynamics of Institutional Innovation'. Eur. J. Dev. Res. 2002, 14, 89-108. [CrossRef]

58. Nkondo, M. Indigenous African Knowledge Systems in A Polyepistemic World: The Capabilities Approach and The Translatability of Knowledge Systems. In The Southern African Regional Colloquium on Indigenous African Knowledge Systems: Methodologies and Epistemologies for Research, Teaching, Learning and Community Engagement In Higher Education; University Of Kwazulu-Natal 23 November 2012; Howard College: Big Spring, TX, USA, 2012.

59. Semali, L.M.; Kincheloe, J.L. Introduction: What is Indigenous Knowledge and Why Should We Study It? In What Is Indigenous Knowledge? Voices from the Academyi; Semali, L.M., Kincheloe, J.L., Eds.; Falmer Press: New York, NY, USA; London, UK, 1999.

60. Koech, K.C.; Ongugo, O.P.J.O; Mbuvi, T.E.M. Community Forest Associations in Kenya: Challenges and Opportunities; Kenya Forestry Research Institute: Nairobi, Kenya, 2009; p. 3. 
61. Oduol, P.A. The Shamba system: An indigenous system of food production from forest areas of Kenya. In Meterology and Agroforestry, Proceeding of the Application of Meteorology to Agroforestry Systyems Planning and Management, Nairobi, Kenya, 9-13 February 1987; Riefsnyder, W.S., Darnhofer, T.S., Eds.; World Agroforestry Centre: Nairobi, Kenya, 1989; pp. 365-373.

62. Witcomb, M.; Dorward, P. An assessment of the benefits and limitations of the shamba agroforestry system in Kenya and of management and policy requirements for its successful and sustainable reintroduction. Agrofor. Syst. 2009, 75, 261-274. [CrossRef]

63. Van Stapele, N. Mediations of Violence in Africa: Fashioning New Futures from contested pasts. In Masculinity, Ethnicity and Violence in Nairobi; Kapteijns, L., Richters, A., Eds.; Brill: Leiden, The Netherlands, 2010.

64. Mathu, W.; Ng'ethe, R. Forest Plantation and Woodlots in Kenya. Afr. For. Forum Work. Pap. 2011, 1, 32.

65. Wandahwa, P.; Van Ranst, E. Qualitative land suitability assessment for pyrethrum cultivation in west Kenya based upon computer-captured expert knowledge and GIS. Agric. Ecosyst. Environ. 1996, 56, 187-202. [CrossRef]

66. Kanyinga, K.; Mkize-Binswanger, H.; Bourguignon, C.; Van den Brink, R. Agricultural Land Redistribution: Towards Greater Consensus; World Bank: Washington, DC, USA, 2009; pp. 87-117.

67. Furedi, F. The Mau Mau War in Perspective; James Currey: London, UK, 1989.

68. Lesorogol, C.K. Contesting the Commons: Privatizing Pastoral Lands in Kenya; University of Michigan Press: Ann Arbor, MI, USA, 2008.

(C) 2018 by the authors. Licensee MDPI, Basel, Switzerland. This article is an open access article distributed under the terms and conditions of the Creative Commons Attribution (CC BY) license (http:// creativecommons.org/licenses/by/4.0/). 